\title{
Traditional Belief and Practice on Postpartum Recovery among Mothers in East Coast of Peninsular Malaysia
}

\author{
Radiah Abdul Ghanil ${ }^{, *}$ and Saezah Salehudin ${ }^{1}$ \\ ${ }^{1}$ Department of Biomedical Science, Kulliyah of Allied Health Sciences International Islamic \\ University Malaysia,25200 Kuantan Pahang
}

\begin{abstract}
Postpartum care is highly important to prevent maternal and infant morbidity. In Malaysia, there are several traditional postpartum care practices by mothers. Different states adopted different ways to perform those practices. In spite of long and established practices in Malaysia, its effect and safety profile is not well understood. This study aims to gain an understanding of the traditional practices that Malay women follow in relation to postpartum care and the rationales underpinning such practices. A cross sectional study $(\mathrm{n}=100)$ was conducted using self-administered questionnaire consists of demographic information, practice of postpartum care and knowledge of postpartum care. Data was analyzed using Statistical Package Social Software (2.0). The findings shown that, there was no significant association of socio-demographic data with confinement period $(p>0.05)$. For postpartum dietary practice, there were only association between age and encourage more water intake $(p=0.047$, $p<0.05)$ and also between number of children and prohibit greasy food $(p=0.032, p<0.05)$. For association between socio-demographic data and postpartum physical practice, there was only association between age and body scrub ( $p=0.046, p<0.05)$. The most significant factor that influenced postpartum care practice and its knowledge was family tradition with $83 \%$ and $97 \%$, respectively. Traditional postpartum care practice is still significant and dominant among mothers in Kuantan, Pahang. This information is important for health care professional to educate women and provide strategies to help them to integrate their beliefs and the practices recommended in contemporary health care practice.
\end{abstract}

\section{Introduction}

Pregnancy and birth are seen as socially important transition periods that should be taken seriously. For women that delivering their first baby, that moment is probably the most significant experience and gives impact in their life [16]. The process to become a mother is defined as a process of learning, discovery, appreciation and acceptance of new role of a woman which leads in a worthwhile and valuable experience [7]. While the postpartum period begins immediately after the birth of the baby and extends for about six

\footnotetext{
* Corresponding author: radiah@iium.edu.my
} 
weeks during which, the mother's body return to the non-pregnant state (WHO,1998). There are also physical changes, strong emotions, altered and new relationships and adaptation to a new role [3].

There are major changes occur during postpartum period in the body that determine mothers' well-being and expected for a healthy future [17]. Complications may come up and if they are not treated immediately and efficaciously can lead to ill-health and death to mothers, babies or both [1]. The risk of morbidity and mortality is highest in the first six weeks after birth but stays high after 6 weeks because of issues such as untreated anaemia or repeat pregnancy [7]. Thus, improvement of delivery of post-partum care has been neglected as a strategy for improving maternal, infant, and child health.

The practices of postpartum care aim to restore the normal function of sexual and reproductive organs, increasing wellbeing and energy of the mothers. The normal feedback mechanism of human body will involve such as wound healing promotion and weight loss. Due to these reasons, postpartum care is a priority programme worldwide which aims to restrain maternal deaths and for aesthetic purposes.

Women in Asian countries are doing well after childbirth compared to those in Western countries [2]. They find that many postpartum complications are nearly non-existent especially postpartum depression. Conversely, $14 \%$ of postnatal mothers suffer moderate to severe postpartum depression in developed countries. They believe this is due to the traditional postpartum care. However, it has still not been fully understood whether postpartum care practices give any significant effect on women's health or not. The health care providers are not able to come out with the benefits or negative effects on health due to inadequate study on the postpartum care practice. In spite of long and established practices in Malaysia, its effect and safety profile is not well understood.

Hence, this study was conducted to identify knowledge and practice of postpartum care among mothers in one area in East Coast of Peninsular Malaysia; Kuantan, Pahang. Moreover, this study aims to determine association of socio-demographic data with confinement period, postpartum dietary practice and postpartum physical practice. It is also to identify factors that influence postpartum care practice among mothers in Kuantan and lastly to investigate factors that contribute to knowledge of postpartum care among mothers in this selected population.

\section{Material and Methods}

Study design and sampling: A cross-sectional study was conducted among 100 respondents among mothers in selected area in Peninsular Malaysia which is Kuantan, Pahang. Subjects were selected by using the method of purposive sampling based on the inclusion criteria which were women who have given live birth from 2013 until 2016, given live birth in Kuantan and the resident of Kuantan, Pahang and exclusion criteria which were women who do not understand Malay or English language and cannot communicate effectively, women who have chronic disease or on medication and also miscarriage and still-birth cases.

The determined sample size for this study was calculated using single proportion sample size calculation formula. The selected subjects were asked to complete a prepared questionnaire which included all appropriate issue of knowledge and practice of postpartum care. The questionnaire was divided into three categories which were personal details, practice of postpartum care and knowledge of postpartum care. The multiple choice and Likert scale format were selected for simplicity in scoring and data management.

Instrument development: The prepared questionnaire included all appropriate issue of knowledge and practice of postpartum care. The questionnaire was divided into three 
categories which were personal details, practice of postpartum care and knowledge of postpartum care. The questions of personal details were age, ethnicity, and religion, level of education, occupation and number of children. Apart from that, for practice of postpartum care, it included confinement period, types of practices, complications, dietary intakes and supplement consumed. The questions in the category of knowledge of postpartum care were to evaluate the basic information about postpartum care such as the origin of knowledge, reason behind the practice and purposes of the practice. The multiple choice and Likert scale format were selected for simplicity in scoring and data management.

Validity and reliability of questionnaire: To validate the accuracy and validity of questionnaire, the content id reviewed by panel of expert. A pilot study was conducted within selected group of 30 among International Islamic University's staff. Results from pilot study showed the Cronbach alpha 0.67 and 0.73 for section B and C, respectively.

Ethical consideration: The approval to conduct this study was obtained from Dean, Kulliyyah of Allied Health Sciences and International Islamic University Malaysia Ethics Committee. The guideline stated was strictly followed before conducting this study. Prior to taking part in this study, respondents were informed about the objective of the study. All respondents were asked to sign on consent form confirming their willingness to participate. All respondents were assured that confidentiality would be maintained.

Statistical analysis:All the collected data was quantitatively analyzed using Statistical Package for Social Sciences (SPSS) version 12. The test used was Chi-square test (to determine association of socio-demographic data with confinement period, postpartum dietary practice and postpartum physical practice). For Chi- square test, the data must meet the assumption by cell with and expected count less than five must be $<20 \%$. The minimum expected count must be $\geq 1$. If the assumption was not met, the Fisher's exact test can be used. The data showed statistical significance relationship with $p$-value $<0.05$.

Figures and tables, as originals of good quality and well contrasted, are to be in their final form, ready for reproduction, pasted in the appropriate place in the text. Try to ensure that the size of the text in your figures is approximately the same size as the main text (10 point). Try to ensure that lines are no thinner than 0.25 point.

\section{Results}

There were 100 eligible mothers participated in this study. The age of respondents ranged from 20 to 49 years old. Most of them were in the age group of 20-29 followed by 30-39. Most of the respondents were Malays, Muslims, employed and had one child. The highest level of education was up to tertiary school. There was no significant association of demographic data which were age, level of education, occupation and number of children with confinement period $(\rho>0.05)$ (Table 1). 
Table 1

Chi-square test for demographic data and confinement period

\begin{tabular}{|c|c|c|c|c|}
\hline Variable & $\begin{array}{c}\leq 44 \text { days } \\
(n=54) \\
n(\%)\end{array}$ & $\begin{array}{c}\geq 45 \text { days } \\
(\mathrm{n}=46) \\
\mathrm{n}(\%)\end{array}$ & $\begin{array}{c}\text { Chi-square } \\
\text { (d.f) }\end{array}$ & $p$-value \\
\hline $\begin{array}{l}\text { Age } \\
\qquad 29 \\
\geq 30\end{array}$ & $\begin{array}{l}31(57.4) \\
23(42.6)\end{array}$ & $\begin{array}{l}19(41.3) \\
27(58.7)\end{array}$ & $\begin{array}{l}2.576 \\
(1)\end{array}$ & 0.108 \\
\hline $\begin{array}{l}\text { Level of education } \\
\text { No formal } \\
\text { education } \\
\text { With education }\end{array}$ & $\begin{array}{c}0(0.0) \\
54(100.0)\end{array}$ & $\begin{array}{c}1(2.2) \\
45(97.8)\end{array}$ & - & $0.460^{*}$ \\
\hline $\begin{array}{l}\text { Job status } \\
\text { Unemployed } \\
\text { Employed }\end{array}$ & $\begin{array}{l}13(24.1) \\
41(75.9)\end{array}$ & $\begin{array}{l}12(26.1) \\
34(73.9)\end{array}$ & $\begin{array}{l}0.054 \\
\text { (1) }\end{array}$ & 0.817 \\
\hline $\begin{array}{l}\text { Number of children } \\
\quad \leq 4 \\
\geq 5\end{array}$ & $\begin{array}{c}52(96.3) \\
2(3.7)\end{array}$ & $\begin{array}{c}44(95.7) \\
2(4.3)\end{array}$ & - & $1.000 *$ \\
\hline
\end{tabular}

Chi-square test for independent (with Fisher's exact test*) indicated that there was statistical significant association between socio-demographic data and confinement period $(p<0.05)$ among mothers in Kuantan.

Table 2

Chi-square test for age and postpartum dietary practice

\begin{tabular}{|c|c|c|c|c|}
\hline Variable & \multicolumn{2}{|c|}{ Prohibit cold food } & \multirow{2}{*}{$\begin{array}{l}\text { Chi-square } \\
\text { (d.f) }\end{array}$} & \multirow[t]{2}{*}{$p$-value } \\
\hline Age & $\begin{array}{c}\text { Yes } \\
(\mathbf{n}=99) \\
\mathbf{n}(\%)\end{array}$ & $\begin{array}{c}\text { No } \\
(\mathbf{n}=\mathbf{1}) \\
\mathbf{n}(\%)\end{array}$ & & \\
\hline $\begin{array}{l}\leq 29 \\
\geq 30\end{array}$ & $\begin{array}{l}49(49.5) \\
50(50.5)\end{array}$ & $\begin{array}{c}1(100.0) \\
0(0.0)\end{array}$ & - & $1.000 *$ \\
\hline Variable & \multicolumn{2}{|c|}{ Prohibit acidic food } & \multirow{2}{*}{$\begin{array}{l}\text { Chi-square } \\
\text { (d.f) }\end{array}$} & \multirow[t]{2}{*}{$p$-value } \\
\hline Age & $\begin{array}{c}\text { Yes } \\
(\mathbf{n}=77) \\
\mathbf{n}(\%)\end{array}$ & $\begin{array}{c}\text { No } \\
(n=23) \\
n(\%)\end{array}$ & & \\
\hline $\begin{array}{l}\leq 29 \\
\geq 30\end{array}$ & $\begin{array}{l}35(45.5) \\
42(54.5)\end{array}$ & $\begin{array}{c}15(65.2) \\
8(34.8)\end{array}$ & $\begin{array}{l}2.767 \\
\text { (1) }\end{array}$ & 0.096 \\
\hline Variable & \multicolumn{2}{|c|}{ Prohibit greasy food } & \multirow{2}{*}{$\begin{array}{l}\text { Chi-square } \\
\text { (d.f) }\end{array}$} & \multirow{2}{*}{$p$-value } \\
\hline Age & $\begin{array}{c}\text { Yes } \\
(n=78) \\
n(\%)\end{array}$ & $\begin{array}{c}\text { No } \\
(n=22) \\
n(\%)\end{array}$ & & \\
\hline $\begin{array}{l}\leq 29 \\
\geq 30\end{array}$ & $\begin{array}{l}35(44.9) \\
43(55.1)\end{array}$ & $\begin{array}{c}15(68.2) \\
7(31.8)\end{array}$ & $\begin{array}{l}3.730 \\
(1)\end{array}$ & 0.053 \\
\hline Variable & \multicolumn{2}{|c|}{ Limit water intake } & \multirow{2}{*}{$\begin{array}{l}\text { Chi-square } \\
\text { (d.f) }\end{array}$} & \multirow[t]{2}{*}{$p$-value } \\
\hline Age & $\begin{array}{c}\text { Yes } \\
(n=29) \\
n(\%)\end{array}$ & $\begin{array}{c}\text { No } \\
(\mathrm{n}=71) \\
\mathrm{n}(\%)\end{array}$ & & \\
\hline $\begin{array}{l}\leq 29 \\
\geq 30\end{array}$ & $\begin{array}{l}13(44.8) \\
10(55.2)\end{array}$ & $\begin{array}{l}37(52.1) \\
34(47.9)\end{array}$ & $\begin{array}{l}0.437 \\
\text { (1) }\end{array}$ & 0.509 \\
\hline Variable & \multicolumn{2}{|c|}{ Encourage warm food } & \multirow{2}{*}{$\begin{array}{l}\text { Chi-square } \\
\text { (d.f) }\end{array}$} & \multirow[t]{2}{*}{$p$-value } \\
\hline Age & $\begin{array}{c}\text { Yes } \\
(\mathbf{n}=\mathbf{5 7}) \\
\mathbf{n}(\%)\end{array}$ & $\begin{array}{c}\text { No } \\
(n=43) \\
n(\%)\end{array}$ & & \\
\hline $\begin{array}{l}\leq 29 \\
\geq 30\end{array}$ & $\begin{array}{l}27(47.4) \\
30(52.6)\end{array}$ & $\begin{array}{l}23(53.5) \\
20(46.5)\end{array}$ & $\begin{array}{l}0.367 \\
\text { (1) }\end{array}$ & 0.545 \\
\hline Variable & \multicolumn{2}{|c|}{ Encourage more water intake } & \multirow{2}{*}{$\begin{array}{l}\text { Chi-square } \\
\text { (d.f) }\end{array}$} & \multirow[t]{2}{*}{$p$-value } \\
\hline Age & $\begin{array}{c}\text { Yes } \\
(n=29) \\
n(\%)\end{array}$ & $\begin{array}{c}\text { No } \\
(n=71) \\
n(\%)\end{array}$ & & \\
\hline $\begin{array}{l}\leq 29 \\
\geq 30\end{array}$ & $\begin{array}{l}10(34.5) \\
19(65.5)\end{array}$ & $\begin{array}{l}40(56.3) \\
31(43.7)\end{array}$ & $\begin{array}{l}3.934 \\
(1)\end{array}$ & 0.047 \\
\hline
\end{tabular}

Chi-square test for independent (with Fisher's exact test *) indicated that there was statistical significant association between age and postpartum dietary practice $(p<0.05)$ among mothers in Kuantan. 
Table 3

Chi-square test for number of children and postpartum dietary practice

\begin{tabular}{|c|c|c|c|c|}
\hline Variable & \multicolumn{2}{|c|}{ Prohibit cold food } & \multirow{2}{*}{$\begin{array}{l}\text { Chi-square } \\
\text { (d.f) }\end{array}$} & \multirow{2}{*}{$p$-value } \\
\hline Number of children & $\begin{array}{c}\text { Yes } \\
(\mathbf{n}=99) \\
\mathbf{n}(\%)\end{array}$ & $\begin{array}{c}\text { No } \\
(n=1) \\
n(\%)\end{array}$ & & \\
\hline $\begin{array}{l}\leq 4 \\
\geq 5\end{array}$ & $\begin{array}{c}95(96.0) \\
4(4.0)\end{array}$ & $\begin{array}{c}1(100.0) \\
0(0.0)\end{array}$ & - & $1.000^{*}$ \\
\hline Variable & \multicolumn{2}{|c|}{ Prohibit acidic food } & \multirow{2}{*}{$\begin{array}{l}\text { Chi-square } \\
\text { (d.f) }\end{array}$} & \multirow[t]{2}{*}{$p$-value } \\
\hline Number of children & $\begin{array}{c}\text { Yes } \\
(\mathbf{n}=77) \\
\mathbf{n}(\%)\end{array}$ & $\begin{array}{c}\text { No } \\
(n=23) \\
n(\%)\end{array}$ & & \\
\hline $\begin{array}{l}\leq 4 \\
\geq 5\end{array}$ & $\begin{aligned} 73 & (94.8) \\
4 & (5.2)\end{aligned}$ & $\begin{array}{c}23(100.0) \\
0(0.0)\end{array}$ & - & $0.571 \%$ \\
\hline Variable & \multicolumn{2}{|c|}{ Prohibit greasy food } & \multirow{2}{*}{$\begin{array}{l}\text { Chi-square } \\
\text { (d.f) }\end{array}$} & \multirow[t]{2}{*}{$p$-value } \\
\hline Number of children & $\begin{array}{c}\text { Yes } \\
(\mathbf{n}=78) \\
n(\%)\end{array}$ & $\begin{array}{c}\text { No } \\
(\mathrm{n}=22) \\
\mathrm{n}(\%)\end{array}$ & & \\
\hline $\begin{array}{l}\leq 4 \\
\geq 5\end{array}$ & $\begin{aligned} 77 & (98.7) \\
1 & (1.3)\end{aligned}$ & $\begin{array}{l}19(86.4) \\
3(13.6)\end{array}$ & - & $0.032 *$ \\
\hline Variable & \multicolumn{2}{|c|}{ Limit water intake } & \multirow{2}{*}{$\begin{array}{c}\text { Chi-square } \\
\text { (d.f) }\end{array}$} & \multirow[t]{2}{*}{$p$-value } \\
\hline Number of children & $\begin{array}{c}Y \text { es } \\
(\mathbf{n}=29) \\
\mathbf{n}(\%)\end{array}$ & $\begin{array}{c}\text { No } \\
(\mathrm{n}=71) \\
\mathrm{n}(\%)\end{array}$ & & \\
\hline $\begin{array}{l}\leq 4 \\
\geq 5\end{array}$ & $\begin{array}{r}27(93.1) \\
2(6.9)\end{array}$ & $\begin{array}{c}69(97.2) \\
2(2.8)\end{array}$ & - & $0.577^{*}$ \\
\hline Variable & \multicolumn{2}{|c|}{ Encourage warm food } & \multirow{2}{*}{$\begin{array}{l}\text { Chi-square } \\
\text { (d.f) }\end{array}$} & \multirow[t]{2}{*}{$p$-value } \\
\hline Number of children & $\begin{array}{c}Y \text { es } \\
(n=54) \\
n(\%)\end{array}$ & $\begin{array}{c}\text { No } \\
(\mathrm{n}=42) \\
\mathrm{n}(\%)\end{array}$ & & \\
\hline $\begin{array}{l}\leq 4 \\
\geq 5\end{array}$ & $\begin{array}{c}54(94.7) \\
3(5.3)\end{array}$ & $\begin{array}{c}42 \text { (97.7) } \\
1(2.3)\end{array}$ & - & $0.632 *$ \\
\hline Variable & \multicolumn{2}{|c|}{ Encourage more water in take } & \multirow{2}{*}{$\begin{array}{c}\text { Chi-square } \\
\text { (d.f) }\end{array}$} & \multirow[t]{2}{*}{$p$-value } \\
\hline Number of children & $\begin{array}{c}\text { Yes } \\
(\mathbf{n}=29) \\
\mathbf{n}(\%)\end{array}$ & $\begin{array}{c}\text { No } \\
(\mathrm{n}=71) \\
\mathrm{n}(\%)\end{array}$ & & \\
\hline $\begin{array}{l}\leq 4 \\
\geq 5\end{array}$ & $\begin{array}{c}27(93.1) \\
2(6.9)\end{array}$ & $\begin{array}{c}69(97.2) \\
2(2.8)\end{array}$ & - & $0.577^{*}$ \\
\hline
\end{tabular}

Chi-square test for independent (with F isher's exact test" ${ }^{*}$ ) indicated that there was statistical significant association between number of children and postpartum dietary practice $(p<0.05)$ among mothers in Kuantan.

Table 4

Association of Socio- Demographic Data and Postpartum Physical Practice

\begin{tabular}{|c|c|c|c|c|}
\hline \multirow{2}{*}{$\begin{array}{c}\text { Variable } \\
\text { Age }\end{array}$} & \multicolumn{2}{|c|}{ Bodly serub } & \multirow{2}{*}{$\begin{array}{c}\text { Chi-square } \\
\text { (d.f) }\end{array}$} & \multirow[t]{2}{*}{$\rho$-value } \\
\hline & $\begin{array}{c}\text { Yes } \\
(\mathbf{m}=\mathbf{2 0}) \\
\mathrm{n}(\%)\end{array}$ & $\begin{array}{c}\text { No } \\
(\mathrm{m}=\mathbf{8 0}) \\
\mathrm{n}(\%)\end{array}$ & & \\
\hline $\begin{array}{l}\leq 29 \\
\geq 30\end{array}$ & $\begin{array}{c}6(30.0) \\
14(70.0)\end{array}$ & $\begin{array}{l}44(55.0) \\
36(45.0)\end{array}$ & $\begin{array}{l}4.000 \\
\text { (1) }\end{array}$ & 0.046 \\
\hline
\end{tabular}

It has been found that not all demographic data (age, level of education, job status and number of children) affected the postpartum dietary practices which consisted of prohibit cold food, prohibit acidic food, prohibit greasy food, limit water intake, encourage warm food and encourage more water intake. There were only association between age and encourage more water intake $(\rho=0.047, \rho<0.05)$ (Table 2$)$ and also between number of children and prohibit greasy food $(\rho=0.032, \rho<0.05)$ for postpartum dietary practice (Table 3 ). Other than these two mentioned practices were not affected by any respondents' sociodemographic data.

There were ten postpartum physical practices which were hot compress, corset, massage, herbs bath, param, pilis, sauna, body scrub, omam and oil bath associated with socio-demographic data (age, level of education, job status and number of children). However, there was only association between age and body scrub $(\rho=0.046, \rho<0.05)$ (Table 4). 


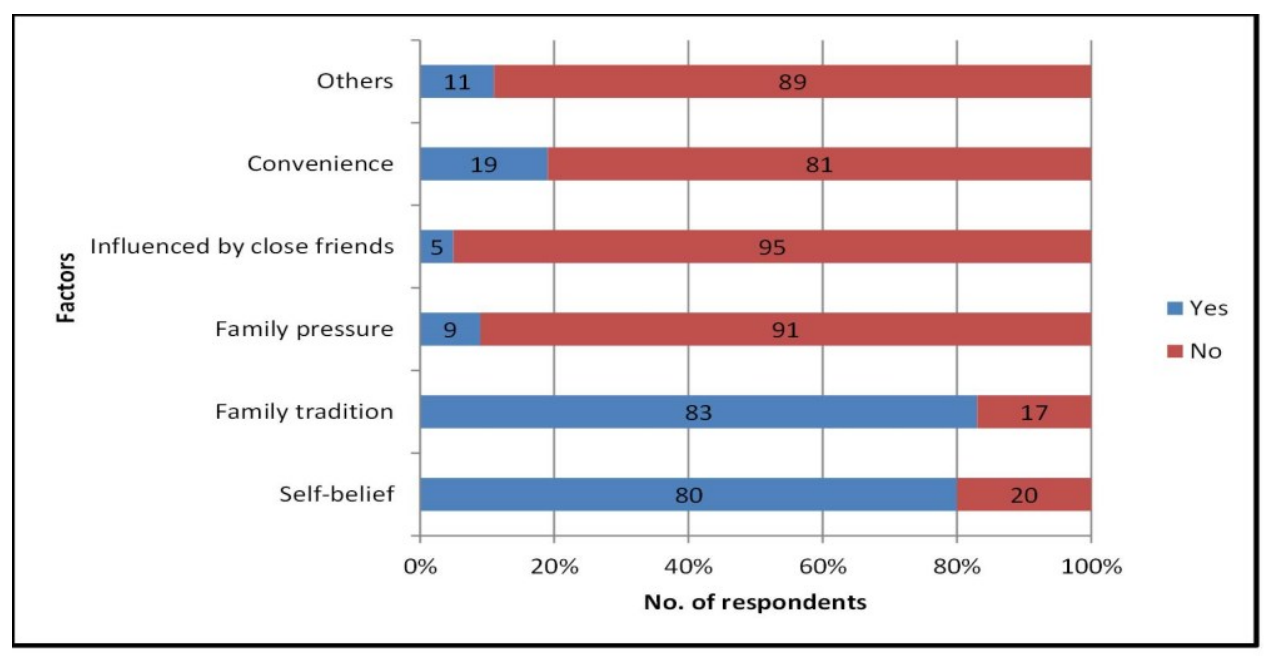

Figure 1

Factors that influence postpartum care practice

The factors that influenced respondents to do postpartum care practice were selfbelief, family tradition, family pressure, influenced by close friends, and convenience. It has been found that the family tradition was the most influenced factor among respondents with $83 \%$ of the mothers. Then, followed by self-belief ( $80 \%)$, convenience $(19 \%)$, other factors $(11 \%)$, and family pressure $(9 \%)$. The effect of close friends was the least factor that influenced respondents to experience postpartum care practice (5\%) (Fig. 1).

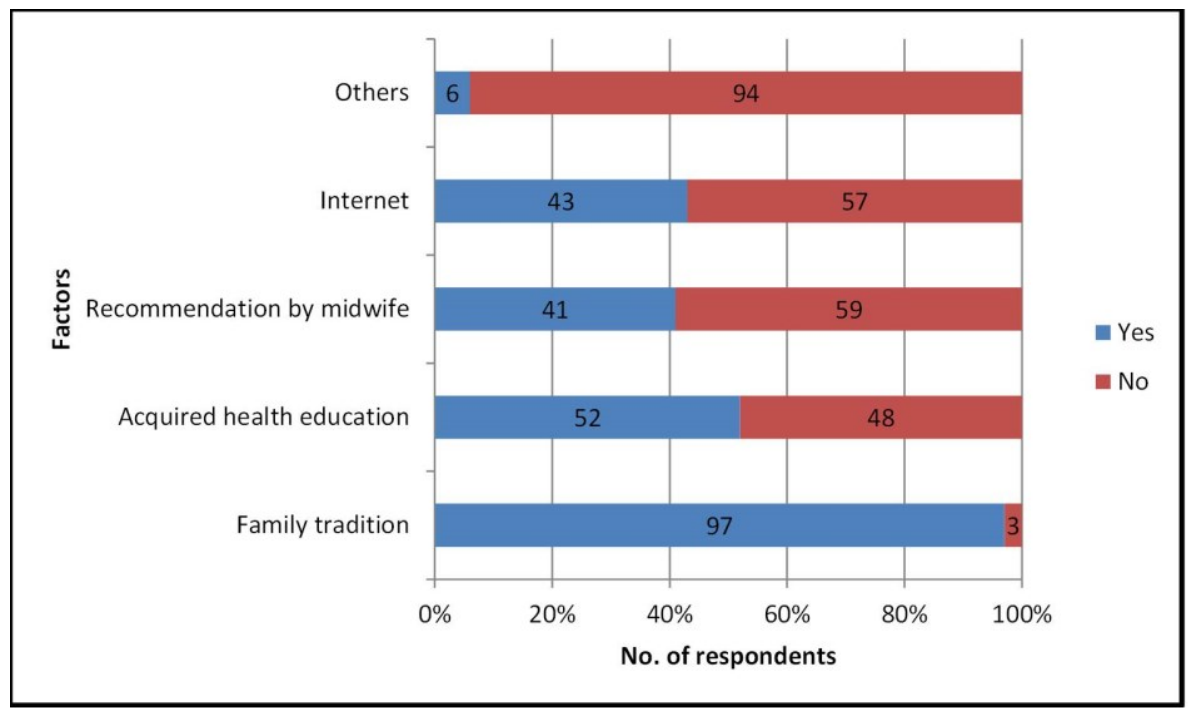

Figure 2

Factors that contribute to knowledge of postpartum care

There were five elements that contribute to knowledge of postpartum care which were family tradition, acquired health education, recommended by midwife, internet and others. Family tradition has contributed the most to knowledge of postpartum care among mothers 
with $97 \%$. The least factor that contributed to postpartum care knowledge was other factors $(6 \%)$. Acquired health education, internet and recommended by midwife have contributed to knowledge of postpartum care with $52 \%, 43 \%$ and $41 \%$, respectively (Fig. 2).

\section{Discussion}

There was no significant association between socio-demographic data with confinement period, which means socio-demographic data did not affect confinement period of the mothers after delivered a baby. This finding was similar to the study done in Penang which was the association between socio-demographic data and confinement period is not statistically significant [9]. It means that the perceived minimum confinement period is not affected by the different settings of the study but it is more likely to be based on the belief of the mothers. Malay women especially Muslim practice a 40-day period of rest based on Islamic beliefs (Stern, 1983). In contrast, Chinese and Indian women practice their confinement for 30 days [4]. Thus, it shows that the confinement period strongly depends on the belief of the mothers and does not influenced by other factors.

For association of socio-demographic data and postpartum dietary practice, there were only two statistically significant associations between socio-demographic data and postpartum dietary practice. There was association between age and encourage more water intake and association between numbers of children and prohibition of greasy food. The encouragement of water intake is good because it can decrease the risk of dehydration and constipation among mothers. Water is the most crucial nutrient for human and the absence of it solely can be lethal within days. Apart from that, the short and long-term effects of water on human health are very clear [10]. However, it was reported that association between socio-demographic data and postpartum dietary practice shows that the mothers are more likely to restrict their water intake even though the limitation of water and certain foods like vegetable and fruit intake may lead to a risk for constipation, dehydration, and malnutrition [10]. It shows that people are not really aware the importance of water in maintaining their health. Nevertheless, the result of a study in Penang on association of socio-demographic and prohibit greasy food by is consistent with this study [9].

The association between socio-demographic data and postpartum physical practice has been explored in this study as well. There was only a significant association between age and body scrub. Majority of the respondents in this study were 20 to 29 years old. Thus, they are likely to concern more on their skincare as young women are very particular about their skin. This is because they want to ensure there are no skin problems especially after childbirth. Skin changes often occur during pregnancy until after delivery due to physiologic changes which can cause several skin problems such as hyperpigmentation and stretch mark [8]. By practicing body scrub, chances to have those problems can be reduced. The ingredients in the scrub and mask products can give healthy, smooth and radiant skin by exerting their effect through absorbingdirt, removing dead cells, brightening the skin and improve blood circulation [6].

However, the same study done in Penang, Malaysia found an opposite result on association between socio-demographic data and postpartum physical practice [9]. They mentioned that there is a statistically significant result between association of sociodemographic data and consumption of traditional herbs as older women are more likely to use or consume traditional herbs. The difference of finding regarding association of sociodemographic data and postpartum physical practice might be due to the exclusion of women more than 49 years old in this study which leads to no elderly group of the respondents. 
Apart from that, family tradition was the most influenced factor of postpartum care practice in this community. The tradition that passes from generation to generation without fail ensures the continuity of postpartum care practice in each family. This finding was supported by the study done in Mangalore, India which claimed that the cultural background of the new mother influences their practice during postpartum period [14]. The studies done in China and Cambodia also have similar result which the new mothers say that they are doing such practices in order to respect the tradition and following the advice of the elders $[3,12]$. However, the opposite result regarding this issue which the practice stem from self-belief of the new mothers also was reported. The factors that influencing the postpartum practice among mothers depends on whether the mothers are the first child mothers or multiparous mothers [5]. The first child mothers tend to practice diligently due to lack of motherhood experience and knowledge. It seems that factors that influenced practice of postpartum care among mothers are very wide and rely on the standpoint of the mothers.

Furthermore, the finding of this study showed that the family tradition has contributed the most to knowledge of postpartum care among mothers. The continuation of postpartum care practice that originated from old generation enhance the knowledge of the mothers. Majority of the families follow the beliefs and practices of their parents and grandparents and adopt them because their ancestors are more knowledgeable about those practices [12]. Family that have been engaged with certain postpartum care practices for decades will ensure the practices are passed to their next generations [5]. Thus, their descendants will also experience the benefits of the practices.

Note that this study is very important in order to support government's mission and vision as tabulated in United Nations Millennium Development Goals (MDG). One of the MDG's goal is to improve maternal health by 2015 [15]. This goal should not be overstated because one of the most leading causes of death for adolescent girls is complications during pregnancy or childbirth. However, most maternal deaths in developing countries are preventable by receiving a proper health care and adequate nutrition. In addition, good postpartum care is not only can save mother's lives but their babies too Consequently, improving maternal health can be the key to achieve MDG 4 which is to reduce child mortality. It can be seen that this study can help to achieve not just one but two of the MDG's goals which are improving maternal health and reducing child mortality.

Hence, by conducting this study, the beneficial knowledge about postpartum care can be disseminated to the mothers to expand their existing knowledge. Consequently, they would be able to distinguish between good and bad in order to make sure their health are assured. Morever, the good postpartum care practices can be encouraged among mothers particularly those that can reduce the complications during confinement. The reduction of postpartum complications can indirectly reduce the number of deaths among the mothers. Hence, this study can contribute to the achievement of the vision and mission of the government.

\section{Conclusion}

In conclusion, knowledge of postpartum care among mothers in Kuantan was good and the practice was prevalent among them. This study indicated that socio-demographic data have influenced certain postpartum dietary practice and postpartum physical practice. Moreover, this study found that the most important factor that influenced both postpartum care practice and knowledge was family tradition. For recommendation, mothers should be exposed to the possibility of complications due to extreme practice of postpartum care. Therefore, the harmful practice can be avoided. Apart from that, this study can be used as a 
foundation to conduct a study among multiracial population. The study would yield interesting results based on racial points of view.

\section{References}

1. Ching-Yu, C., Eileen, R.F.,\& Lorraine, O.W. Postpartum Maternal Health Care in the United States: A Critical Review. The Journal of Perinatal Education. 15 (2006)

2. Fort, M.A.L., Kothari, T \& Abderrahim, N. Postpartum Care: Levels and Determinants in Developing Countries. USA.15. (2006)

3. Koung Lo., Postpartum Practices among Cambodian Mother in Preah Vihear Province: A Qualitative Study of Beliefs and Practices.Thesis (M.Arts).Mahidol University, (2007)

4. Laderman, C., Destructive health and cooling prayer: Malay humoralism in pregnancy, childbirth and the postpartum period. Social Science and Medicine. 25 (4). 357-365, (1987)

5. Le, M.T., Wanawipha, P., \& Oratai, R., Traditional postpartum practices among Vietnamese mothers in Anthi district, HungYen province. Thesis. Mahidol University, (2003)

6. Magestuti., Subehan., Aty Widyawaruyanti., Syed Faisal Haider Zaidi., Suresh Awale., \& Shigetoshi Kadota., Traditional Medicine of Madura Island in Indonesia. Journal of Traditional Medicine. 24 (3). 90-103, (2007)

7. Martell, L. K., Heading toward the new normal: A contemporary postpartum experience. Journal of Obstetric, Gynecologic, and Neonatal Nursing, 30 (2001). 496-506, (2001)

8. Martin, A.G., \& Leal-Khouri, S., Physiologic Skin Changes Associated with Pregnancy. International Journal of Dermatology. 31(6). 375-378, (2007)

9. Munirah Hishamshah., Muhammad Sirri 'Ammar bin Ramzan., Abdul Rashid., Wan Nur Hidayah bt Wan Mustaffa., Raihanah Haroon., \& Nur Baizura bt Badaruddin., Belief and Practices of Traditional Post Partum Care Among a Rural Community in Penang Malaysia. The Internet Journal of Third World Medicine, 9 (2), (2011)

10. Poh, B.K., Wong, Y.P., \& Norimah A. Karim., Postpartum Dietary Intakes and Food Taboos Among Chinese Women Attending Maternal and Child Health Clinics and Maternity Hospital, Kuala Lumpur. Mal J Nutr, 11(1), 1-21, (2005)

11. Popkin, B.M., D'Anci, K.E., \& Rosenberg, I.H., Water, Hydration and Health. Nutrition Reviews. 68(8). 439-458, (2010)

12. Raven, J. H., Chen, Q., Tolhurst, R. J., \& Garner, P., Traditional beliefs and practices in the postpartum period in Fujian Province, China: a qualitative study. BMC Pregnancy and Childbirth, 7(8), (2007)

13. Stern, G., \& Kruckman, L., Multi-disciplinary perspectives on postpartum depression: An Anthropological Critique.Social Science and Medicine. 17 1027$1041,(1983)$

14. Sunanda, B., \& Shynee, P., A Study on the Cultural Practices of Postnatal Mothers in Selected Hospitals at Mangalore. Nitte University Journal of Health Science. 3(3), (2013)

15. United Nations. The Millennium Development Goals Report 2013. Retrieved April,29,2014fromhttp://www.undp.org/content/undp/en/home/mdgoverview/mdg _goals/mdg5/,(2013) 
16. World Health Organization, Postpartum Care of the Mother and Newborn: A practical Guide. Geneva, . (1998)

17. World Health Organization., WHO Technical Consultation on Postpartum and Postnatal Care. Geneva, (2010) 